\title{
Production of Helianthus annuus L. (Co (SF H)2) in Delta through Cluster Front line Demonstrations
}

\author{
G. Amuthaselvi*, V. Dhanushkodi and Noorjehan A. K. A. Hanif
}

Subject Matter Specialist, Krishi Vigyan Kendra, Tiruchirapalli, Tamil Nadu Agricultural University, India

*Corresponding author

\section{A B S T R A C T}

Keywords

Sunflower, Imidachloprid, yield, Biocontrol agents

\section{Article Info}

\section{Accepted:}

10 January 2021

Available Online:

10 February 2021
The cluster front line demonstration of sunflower (Helianthus annuus L.) was conducted at Tiruchirapalli district during 2017-18 in the farmers field in different locations through cluster front line demonstration. An area of 20 ha at 40 beneficiaries field of three blocks. Results revealed that average highest yield $19.86 \mathrm{q} /$ ha found in demonstration plot followed by $13.15 \mathrm{q} / \mathrm{ha}$ in control plot. The same trend found in case of CFLDs gross and net monetary returns, was Rs. 73733/- and Rs. 46019/- ha and for control Rs. 50180/- and Rs. 21430/-ha, respectively. Benefit cost ratio for demonstration and control was 2.66 and 1.75 respectively. It can be concluded that the oilseed production could be enhanced by encouraging the farmers through adoption of recommended technologies which were followed in the CFLDs. with latest technologies.

\section{Introduction}

Sunflower (Helianthus annuus L.) is an important oil seeds and good source of vegetable oil crop in India. The major goal of growing sunflower is for its seed that contains oil (36-52\%) and protein $(28-32 \%)$ as reported by Rosa et al., (2009). After soybean, sunflower (Helianthus annuus L.) is the second important source of vegetable oil in the world. In India, it is mostly grown in the states of Karnataka, Maharashtra, Andhra Pradesh and Tamil Nadu with potential scope of growing in non-traditional areas like West Bengal (Dutta, 2011). In Tamil Nadu it is grown in summer season as of its short duration crop characteristics and it its well in multiple cropping systems. In Tiruchirapalli district, during summer time farmers are cultivating Sunflower after paddy harvest. The last year production of sunflower in Tiruchirapalli district is 3993ha. It has been reported that sunflower oil is good source of nutrients, vitamins, minerals and antioxidants. The sunflower oil is gaining more importance as it is free from acid and rich in Vitamin-A, roasted sunflower seeds are also used as snacks. Because of increment in domestic consumption of sunflower edible oil, its cultivation is in critical situation in India. The 
yield of the crop is low due to lack of awareness on improved seeds and cultivation practices. The "Cluster Frontline Demonstrations on Rabi Oilseed 2017-18' 'to ICAR-ATARI, Bengaluru through National Mission on Oilseeds, a scheme sponsored by central government. This project was implemented in Krishi Vigyan Kendra (KVK) with main objective to increase the production and productivity through Frontline demonstrations (FLDs) with latest technologies.

\section{Materials and Methods}

The cluster front line demonstration of sunflower was conducted at Three blocks of Tiruchirapalli district. Tiruchirapalli during 2017-18 in the farmers field in different locations through cluster front line demonstration. The blocks are namely Musiri, Thuraiyur and Thathanghayarpettai, an area of 20 ha at 40 beneficiaries field. The sunflower seed was treated with Imidachloprid $7.5 \mathrm{ml} / \mathrm{ha}$ to avoid pest and disease. The following critical inputs viz., sunflower seed $(\mathrm{Co}(\mathrm{SF} \mathrm{H}) 2)$, TNAU Mineral mixture (Sunflower), Integrated Nutrient Management and Integrated PM kit were distributed to beneficiaries.

Farmers were trained to follow the package and practices for sunflower cultivation as recommended by the Tamil Nadu Agricultural University and need based input materials provided to the farmers.

The farmers followed the full package of practices like seed treatment, bio fertilizer Inoculation, fertilizer application, water and weed management, insect-pest management etc. In case of local check, the traditional practices were followed in existing varieties by the farmers. The yield parameters were recorded for both check and demonstrated variety of sunflower.

\section{Results and Discussion}

The total number of twenty eighty Frontline demonstrations on sunflower seed was laid out in an area of 20 hectares in farmer's field in Veeramachanpatti, Kallur and Chennakarai, villages of Tiruchirapalli district in Tamil Nadu. This variety gave the average yield of $16.90 \mathrm{q} / \mathrm{ha}$ in district. After the improved treatment with Imidacloprid 70 ws @ $7 \mathrm{~g} / \mathrm{kg}$ and line sowing method. Farm Yard Manure of $10 \mathrm{t} / \mathrm{ha}$ ha was applied for basal. Integrated nutrient management was followed as per soil test management. TNAU MN mixture@10 kg / ha was applied at the time of sowing. Pheromone traps were used to monitor the pod borer incidence and suitable management practices i.e., application of insecticides was done (Table 1 and 2).

Table.1 Differences between farmers' practices and technological intervention for Sunflower

\begin{tabular}{|l|l|l|}
\hline S.No. & Particulars & Demonstration Package \\
\hline $\mathbf{1}$ & Variety & Co(SF H)2 \\
\hline $\mathbf{2}$ & Seed treatment & Imidachloprid \\
\hline $\mathbf{3}$ & Time of Sowing & End of March 2018 \\
\hline $\mathbf{4}$ & Package of Practices & $\begin{array}{l}\text { Seed treatment } \\
\text { Integrated crop management and Integrated Pest and } \\
\text { Disease Management }\end{array}$ \\
\hline $\mathbf{5}$ & Bio control Agents & $\begin{array}{l}\text { Pseudomonas fluorescens } \\
\text { Rhizobium }\end{array}$ \\
\hline
\end{tabular}


Table.2 Details of yield and economics of cluster frontline demonstration on Sunflower

\begin{tabular}{|l|c|c|c|c|c|}
\hline Treatment & $\begin{array}{c}\text { Yield } \\
\text { (q/ha) }\end{array}$ & $\begin{array}{c}\text { Gross cost } \\
\text { (Rs./ha) }\end{array}$ & $\begin{array}{c}\text { Gross } \\
\text { Income } \\
\text { (Rs./ha) }\end{array}$ & $\begin{array}{c}\text { Net Income } \\
\text { (Rs./ha) }\end{array}$ & B:C ratio \\
\hline Farmers practices & 13.15 & 28750 & 50180 & 21430 & 1.75 \\
\hline $\begin{array}{l}\text { Designer seed + Bio } \\
\text { control agents + } \\
\text { Pheromone traps }\end{array}$ & 19.86 & 27714 & 73733 & 46019 & 2.66 \\
\hline
\end{tabular}

Results concluded that average highest yield $19.86 \mathrm{q} / \mathrm{ha}$ found in demonstration plot followed by 13.15 /ha in control plot. The same trend found in case of CFLDs gross and net monetary returns, was Rs. 73733/- and Rs. 46019/- ha and for control Rs. 50180/- and Rs. 21430/-ha, respectively. Benefit cost ratio for demonstration and control was 2.66 and 1.75 respectively. This improvement in yield might be due to the application of seed treatment, use of biofertilizers, timely weed and water management and integrated pest management practices.

The findings of the study revealed that, the per cent increment in yield of sunflower to the extent of $33.65 \%$ in Cluster Frontline Demonstrations over the farmers practice created greater awareness and motivated the other farmers to adopt the improved package of practices of sunflower. These demonstration trails also enhance the relationship and confidence between farmers and KVK scientists. The recipient farmers of Cluster Frontline Demonstrations also play an important role as source of information and quality seeds for wider dissemination of the improved varieties of sunflower for other nearby farmers. It is concluded that the Cluster Frontline Demonstrations programme is a successful tool in enhancing the production and productivity of sunflower crop through changing the knowledge, attitude and skill of farmers.

\section{References}

Dutta A 2011. Effects of sowing dates on yield and yield components of hybrid sunflower ( $H$. annuus $\mathrm{L})$ in nontraditional areas of West Bengal. Journal of Crop and Weed, 7(2): 226228

Rosa, P.M., Antoniassi, R., Freitas, S.C., Bizzo, H.R., Zanotto, D.L., Oliveira, M.F., Castiglioni, V.B.R., 2009. Chemical composition of Brazilian sunflower varieties. Helia 32: 145-156.

\section{How to cite this article:}

Amuthaselvi, G., V. Dhanushkodi and Noorjehan A. K. A. Hanif. 2021. Production of Helianthus annuus L. $(\mathrm{Co}(\mathrm{SF} \mathrm{H}) 2)$ in Delta through Cluster Front line Demonstrations. Int.J.Curr.Microbiol.App.Sci. 10(02): 1024-1026.

doi: https://doi.org/10.20546/ijcmas.2021.1002.120 